\title{
PENGARUH SUDUT KEMIRINGAN TIANG PANCANG BATTER PILE TERHADAP DAYA DUKUNG AKSIAL DAN LATERAL
}

\author{
Clifford Harri ${ }^{1}$ dan Alfred Jonathan Susilo ${ }^{2}$ \\ ${ }^{1}$ Program Studi Sarjana Teknik Sipil, Universitas Tarumanagara, Jl. Letjen S. Parman No.1 Jakarta \\ Email: cliffhmail@gmail.com \\ ${ }^{2}$ Program Studi Sarjana Teknik Sipil, Universitas Tarumanagara, Jl. Letjen S. Parman No.1 Jakarta \\ Email: alfredsusilo@gmail.com
}

\begin{abstract}
ABSTRAK
Tiang pancang Batter Pile merupakan salah satu bentuk rekayasa pondasi yang bertujuan untuk meningkatkan daya dukung lateral pondasi. Tiang Batter Pile dipancang dengan sudut kemiringan tertentu. Kemiringan tiang mempengaruhi daya dukung aksial dan lateral. Penelitian ini dilakukan untuk memahami perubahan daya dukung aksial dan lateral pada tiang pancang Batter Pile. Perhitungan daya dukung aksial dan lateral dilakukan dengan parameter tiang pancang diameter $350 \mathrm{~mm}$ dan perhitungan dilakukan pada kemiringan $0^{\circ}$ hingga $+25^{\circ}$. Hasil perhitungan menunjukkan peningkatan daya dukung aksial dan lateral. Peningkatan daya dukung lateral optimal pada rentang kemiringan $+15^{\circ}$ hingga $+20^{\circ}$.
\end{abstract}

Kata kunci: tiang pancang, batter pile, batter angle, daya dukung lateral.

\section{PENDAHULUAN}

Menurut data dari Deputi Kedaulatan Maritim Kementerian Koordinator Bidang Kemaritiman (2017), Indonesia memiliki 17.504 pulau, dengan 16.056 di antaranya telah dibakukan namanya pada Kelompok Pakar untuk Nama Geografis Perserikatan Bangsa-Bangsa (UNGEGN). Menurut data dari Kementrian Kelautan dan Perikanan (2018), luas lautan Indonesia mencapai $74 \%$ dari total keseluruhan luas wilayah Indonesia, yaitu seluas 5,8 juta $\mathrm{km} 2$ dari luas keseluruhan 7,81 juta $\mathrm{km} 2$.

Salah satu infrastruktur kemaritiman yang paling penting adalah pelabuhan. Pembangunan pelabuhan di Indonesia saat ini mendapatkan perhatian khusus dari pemerintah Indonesia. Sejak tahun 2014, pemerintah Indonesia telah menyetujui rencana pengembangan infrastruktur kemaritiman dengan total anggaran mencapai 700 triliun rupiah, dengan 243 triliun di antaranya khusus untuk pengembangan 24 pelabuhan strategis.

Perancangan konstruksi pelabuhan, terutama konstruksi dermaga, memerlukan perhatian khusus. Terdapat beberapa faktor yang membedakan perancangan konstruksi konvensional dengan perancangan konstruksi di daerah pesisir/pantai, terutama akibat pengaruh geografis. Salah satu faktor yang perlu dipertimbangkan adalah pengaruh geografis yang unik seperti beban lateral akibat gelombang air laut.

Dalam konstruksi pondasi, konstruksi Batter Pile merupakan salah satu bentuk upaya adaptasi yang sesuai untuk aplikasi di daerah pesisir. Konsep pondasi Batter Pile memasang tiang pondasi pada sudut kemiringan tertentu. Dengan konstruksi tiang bersudut, konstruksi Batter Pile memiliki resistensi terhadap beban lateral yang lebih baik dibanding konstruksi tiang biasa dengan spesifikasi yang sama. Hal ini dapat dicapai karena pada konstruksi Batter Pile, sebagian beban lateral akan disalurkan dalam bentuk beban aksial.

\section{Batter Pile}

Konstruksi Batter Pile (atau disebut juga Battered Pile atau Raked Pile atau Inclined Pile) adalah teknik pemasangan tiang dengan memposisikan tiang pada kemiringan terhadap posisi vertikal dengan sudut tertentu. Menurut Murthy (2002), Batter Pile berdasarkan arah kemiringannya dibagi menjadi dua yaitu Batter Pile 'positif' yaitu tiang dengan kemiringan terhadap posisi vertikal searah dengan beban lateral dan Batter Pile 'negatif' yaitu tiang dengan kemiringan terhadap posisi vertikal berlawanan dengan beban lateral. Menurut Hannigan, et al. (2016), Batter Pile umumnya digunakan untuk meningkatkan daya dukung lateral dari sekelompok tiang jika tiang vertikal tidak dapat menyediakan daya dukung yang dibutuhkan. 

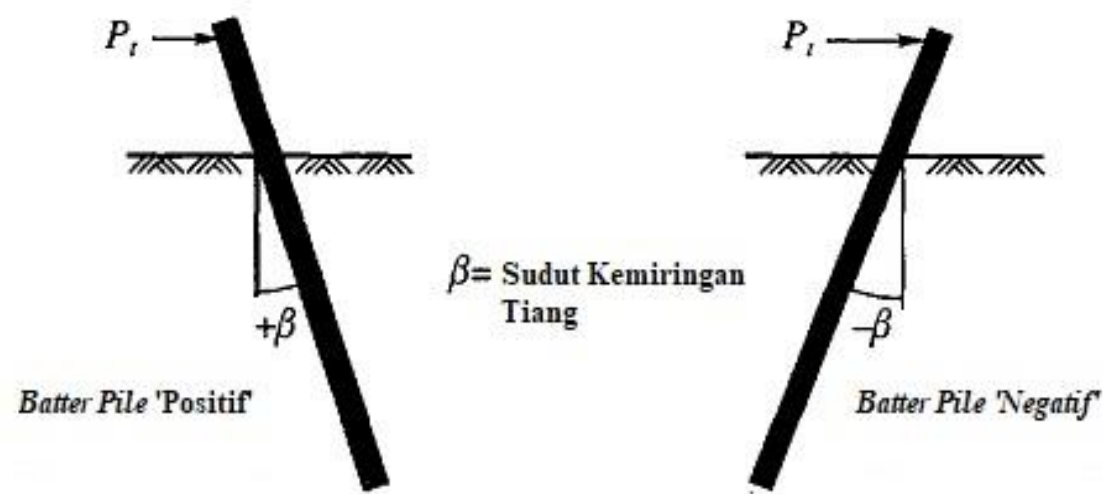

Gambar 1. Dua Jenis Batter Pile berdasarkan arah kemiringannya terhadap posisi vertical (Murthy, 2002)

\section{Perhitungan Daya Dukung Aksial Batter Pile dengan Metode Analisis Kurva p-y}

Analisis daya dukung aksial pada tiang Batter Pile dalam penelitian ini akan dilakukan dengan menggunakan software komputer. Proses analisis ini dibagi menjadi beberapa tahapan antara lain tahap pemasukan data, tahap perhitungan dan kemudian analisis hasil. Tahap pemasukan data terdiri dari beberapa langkah yaitu menentukan judul proyek, standar satuan, jenis tiang, profil tiang, parameter tiang, jenis pembebanan, parameter tanah dan factor of safety. Kemudian kalkulasik akan dilakukan oleh software komputer.

\section{Perhitungan Daya Dukung Lateral Batter Pile dengan Metode Analisis Kurva p-y}

Metode kurva p-y adalah sebuah fungsi yang menggambarkan karakteristik reaksi dari tiang dan tanah secara nonlinier, di mana ' $p$ ' melambangkan daya dukung tanah per satuan panjang tiang sedangkan ' $y$ ' melambangkan lendutan lateral tiang. Langkah-langkah dalam pembuatan kurva p-y untuk tanah lempung antara lain:

1. Menyiapkan data parameter tanah. Data yang diperlukan berupa kuat geser terdrainase $\left(\mathrm{c}_{\mathrm{u}}\right)$ dan berat jenis tanah jenuh $\left(\gamma_{\text {sat }}\right)$

2. Menentukan nilai koefesien $\varepsilon 50$, nilai koefesien ini dapat ditentukan dengan menggunakan kurva tekan-tarik tanah.

3. Menghitung nilai daya dukung maksimal tiang per satuan panjang $\left(P_{u l t}\right)$ dengan menggunakan persamaanpersamaan sebagai berikut;

dan

$$
P_{u l t}=\left(3+\frac{\gamma}{C_{u}} z+\frac{J}{b} z\right) C_{u} b
$$

$$
P_{u l t}=9 C_{u} b
$$

dengan $\mathrm{P}_{\mathrm{ult}}=$ daya dukung maksimal tiang, $\gamma=$ berat jenis tanah rata-rata, $\mathrm{z}=$ kedalaman, $\mathrm{cu}=$ kuat geser pada kedalaman $\mathrm{z}, \mathrm{b}=$ diameter tiang dan $\mathrm{J}=$ koefesien eksperimental.

4. Menentukan Nilai $P_{u l t}$ yang akan digunakan. Nilai yang akan digunakan adalah salah satu nilai yang didapat dari persamaan 1 dan 2, diambil nilai yang terkecil.

5. Menghitung nilai defleksi $y_{50}$ dengan menggunakan persamaan sebagai berikut;

$$
y_{50}=2.5 \varepsilon_{50} b
$$

dengan $\varepsilon_{50}=$ nilai koefesien berdasarkan kurva tekan-tarik dan $b=$ diameter tiang.

6. Setelah didapat nilai $P_{u l t}$ dan $\varepsilon_{50}$, nilai-nilai tersebut digunakan untuk menghitung nilai $p$ yang menjadi elemen sumbu vertikal dengan perbandingan lurus dengan nilai $y$ yang menjadi elemen sumbu horizontal pada kurva p-y dengan menggunakan persamaan sebagai berikut;

$$
\frac{P}{P_{u l t}}=0.5\left(\frac{y}{y_{50}}\right)^{\frac{1}{3}}
$$

Menurut Reese dan Van Impe (2001), nilai $p$ akan mencapai nilai konstan saat nilai $y=8 y_{50}$.

Pengaruh dari kemiringan tiang terhadap kurva p-y telah diteliti oleh Awoshika dan Reese (1971) dalam sebuah model tanki, serta oleh Kubo (1964) dalam pengujian berskala penuh. Berdasarkan hasil pengujian-pengujian tersebut, Awoshika dan Reese (1971) mengajukan sebuah kurva untuk menentukan faktor modifikasi yang dapat digunakan dalam pembuatan kurva p-y untuk tiang pancang bersudut. Kurva tersebut dapat diamati pada Gambar 2. 


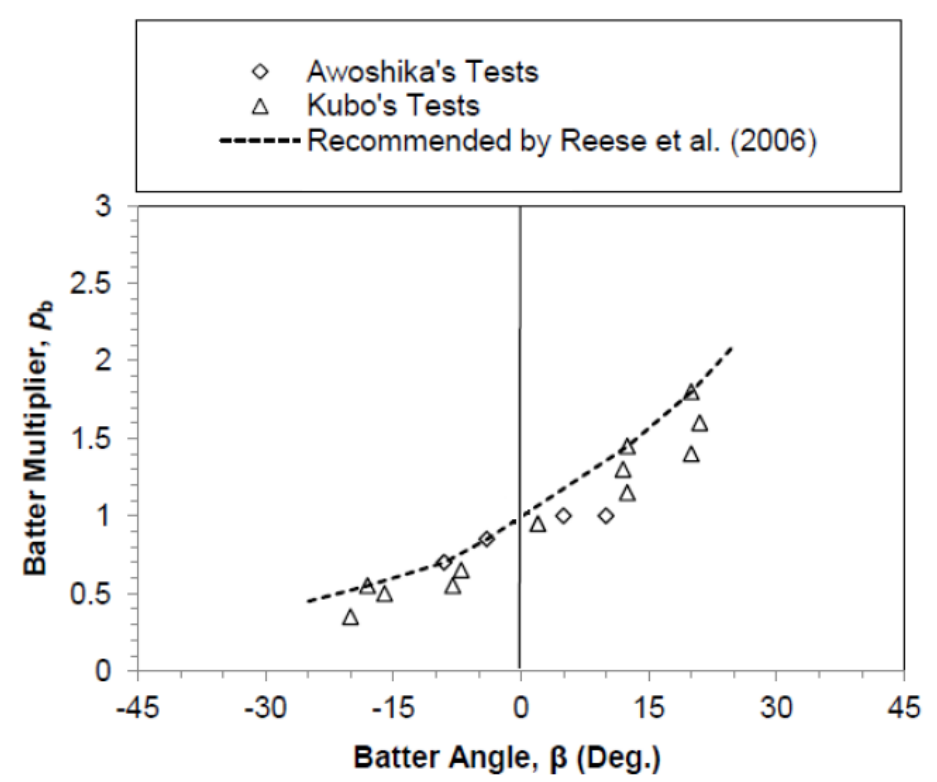

Gambar 2. Faktor Modifikasi yang Diusulkan untuk Tiang Pancang Batter Pile (Boeckmann, 2018)

\section{METODE PENELITIAN}

Dalam penelitian ini, digunakan metodologi analisis dengan software komputer dan analisis dengan perhitungan manual. Diagram alur dibuat dengan tujuan menjelaskan langkah-langkah penelitian hingga dapat ditariknya kesimpulan.

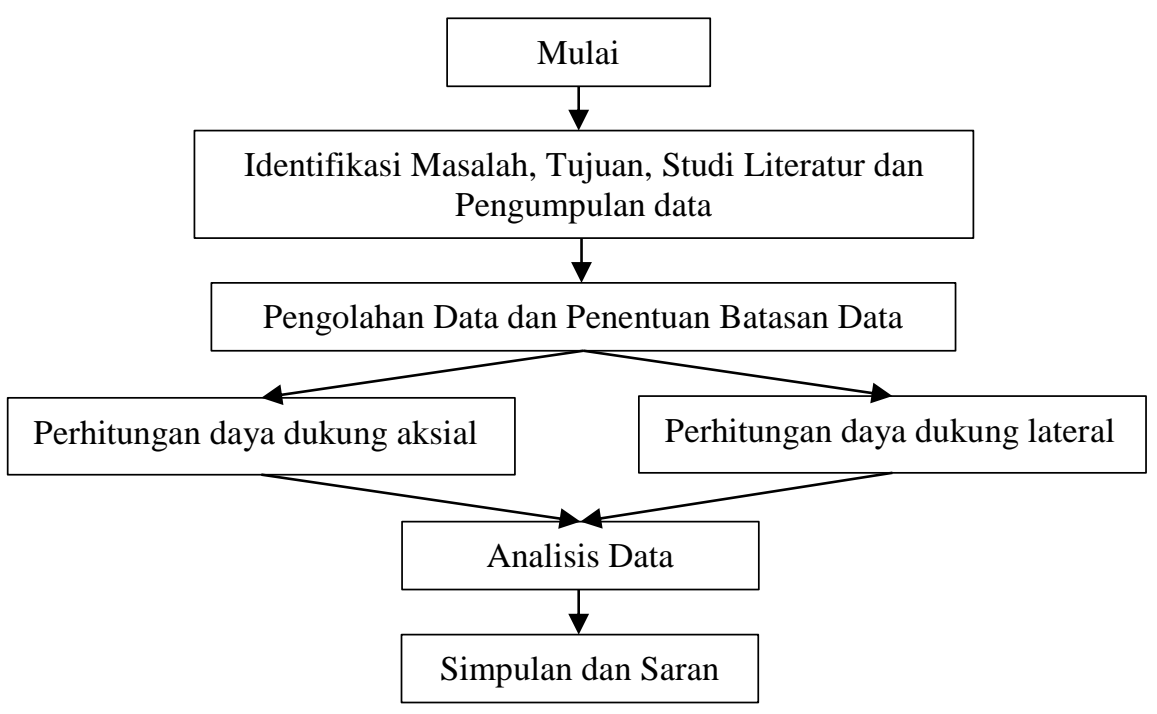

Gambar 3. Diagram Alur Penelitian

\section{HASIL DAN PEMBAHASAN}

\section{Data tanah}

Susunan lapisan tanah dibuat berdasarkan hasil pengujian SPT dan laboratorium yang didapatkan saat proses pengumpulan data. Data yang tidak tersedia dari hasil pengujian didapatkan dengan melakukan korelasi atau pendekatan. Data tanah yang digunakan dapat dilihat pada tabel-tabel berikut; 
Tabel 1. Data Tanah berdasarkan Boring $\log 1$

\begin{tabular}{cccccccc}
\hline Kedalaman $(\mathrm{m})$ & \multirow{2}{*}{$\mathrm{N}-\mathrm{SPT}$} & $\mathrm{c} / \mathrm{c}^{\prime}$ & $\phi$ & $\gamma\left(\mathrm{kN} / \mathrm{m}^{3}\right)$ & $\mathrm{Gs}$ & $\mathrm{e}_{\mathrm{o}}$ & $\mathrm{c}_{\mathrm{u}}$ \\
\hline $0-26$ & 1 & 0.03 & 0 & 14.7 & 2.62 & 2.23 & 7 \\
\hline $27-30$ & 8 & 0.21 & 9 & 15.1 & 2.68 & 1.01 & 56 \\
\hline $31-35$ & 10 & - & - & 18.6 & - & - & 70 \\
\hline $36-40$ & 13 & - & - & 18.6 & - & - & 91 \\
\hline $41-45$ & 16 & - & - & 18.6 & - & - & 112 \\
\hline $46-50$ & 20 & - & - & 19.6 & - & - & 140 \\
\hline $51-60$ & 23 & - & - & 19.6 & - & - & 161 \\
\hline
\end{tabular}

Tabel 2. Data Tanah berdasarkan Boring $\log 2$

\begin{tabular}{cccccccc}
\hline Kedalaman $(\mathrm{m})$ & \multirow{2}{*}{ N-SPT } & $\mathrm{c} / \mathrm{c}{ }^{\prime}$ & $\phi$ & $\gamma(\mathrm{kN} / \mathrm{m} 3)$ & Gs & eo & cu \\
\hline $0-16$ & 1 & 0.03 & 0 & 14.5 & 2.58 & 2.41 & 7 \\
\hline $17-25$ & 11 & 0.03 & 7 & 14.7 & 2.56 & 2.25 & 77 \\
\hline $26-40$ & 13 & - & - & 18.9 & - & - & 91 \\
\hline $41-48$ & 15 & - & - & 18.9 & - & - & 105 \\
\hline $49-60$ & 21 & - & - & 19.6 & - & - & 147 \\
\hline
\end{tabular}

Tabel 3. Data Tanah berdasarkan Boring $\log 3$

\begin{tabular}{cccccccc}
\hline Kedalaman $(\mathrm{m})$ & N-SPT & $\mathrm{c} / \mathrm{c}$ & $\phi$ & $\gamma\left(\mathrm{kN} / \mathrm{m}^{3}\right)$ & $\mathrm{Gs}$ & $\mathrm{e}_{\mathrm{o}}$ & $\mathrm{c}_{\mathrm{u}}$ \\
\hline $0-8$ & 1 & 0.05 & 23 & 15.9 & 2.62 & 1.72 & 7 \\
\hline $9-20$ & 11 & 0.06 & 6 & 15.2 & 2.69 & 2.18 & 77 \\
\hline $21-28$ & 14 & - & - & 18.9 & - & - & 98 \\
\hline $29-50$ & 15 & - & - & 18.9 & - & - & 105 \\
\hline $51-60$ & 23 & - & - & 19.6 & - & - & 161 \\
\hline
\end{tabular}

\section{Analisis daya dukung aksial tiang pancang batter pile dengan software komputer}

Analisis dilakukan pada ketiga data boring log dengan menggunakan software komputer. Parameter yang digunakan antara lain; Pile Type $=$ Driving Conrete Pile, Units $=$ Metric, tiang beton (concrete) dengan diameter $350 \mathrm{~mm}$, luas penampang efektif $96211 \mathrm{~mm}^{2}$, tiang tunggal free head dengan beban statis dan faktor keamanan yang digunakan baik untuk daya dukung selimut maupun daya dukung ujung tiang adalah 2. Dalam penelitian ini, panjang tiang yang digunakan disesuaikan dengan kemiringan tiang dan kedalaman lapisan tanah ujung. Kedalaman lapisan tanah ujung yang digunakan pada ketiga data tanah adalah 51 meter. Profil tiang yang digunakan dapat dilihat dalam tabel 4.

Tabel 4. Profil Tiang yang Digunakan

\begin{tabular}{cc}
\hline Kemiringan Tiang (Batter Angle) & Panjang Tiang \\
\hline $0^{\circ}$ & 51 meter \\
\hline $5^{\circ}$ & 51.2 meter \\
\hline $10^{\circ}$ & 51.8 meter \\
\hline $15^{\circ}$ & 52.8 meter \\
\hline $20^{\circ}$ & 54.3 meter \\
\hline $25^{\circ}$ & 56.3 meter \\
\hline
\end{tabular}

Hasil analisis daya dukung aksial terdiri dari daya dukung selimut izin, daya dukung ujung izin dan daya dukung izin (total). Hasil analisis dapat dilihat pada Gambar 4-6.

\section{Analisis Daya Dukung Lateral Tiang Pancang Batter Pile dengan Metode Kurva p-y}

Analisis daya dukung lateral dilakukan pada ketiga data boring log yang digunakan. Analisis dilakukan pada setiap kedalaman atau panjang tiang dan plot kurva dilakukan pada kedalaman 1 meter, 15 meter dan 30 meter. Analisis kemudian diulangi kembali pada kondisi tiang miring dengan sudut tertentu dengan mempertimbangkan faktor modifikasi untuk tiang batter pile.

Hasil analisis daya dukung lateral dapat dilihat pada Gambar 7-9. 


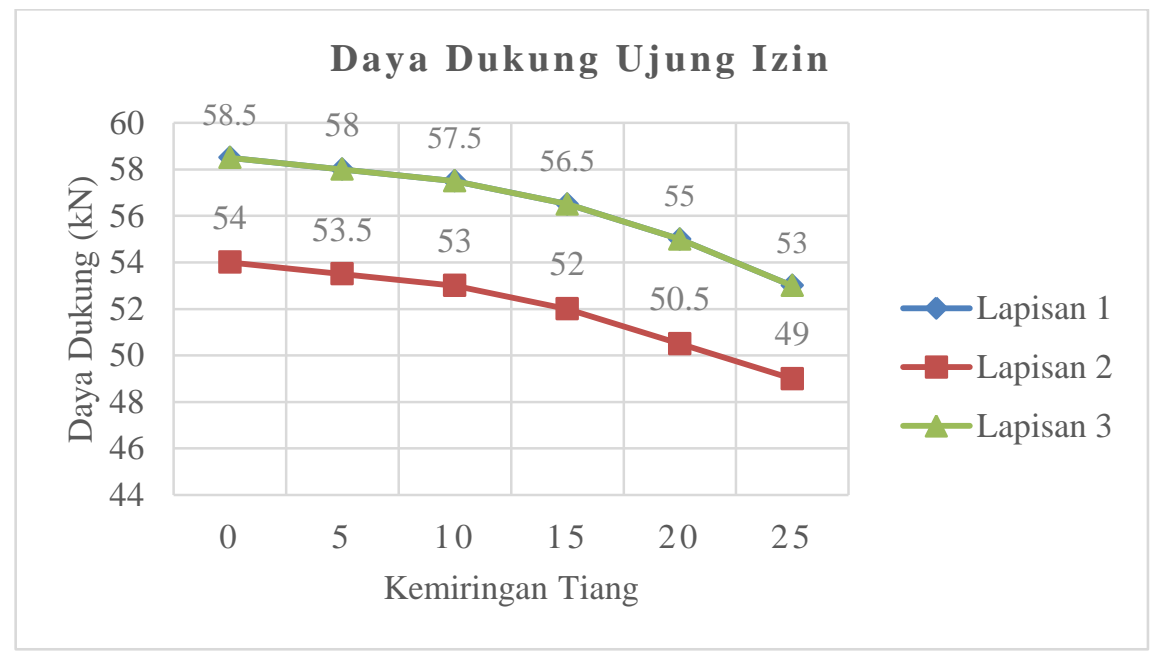

Gambar 4. Perubahan Daya Dukung Ujung Izin

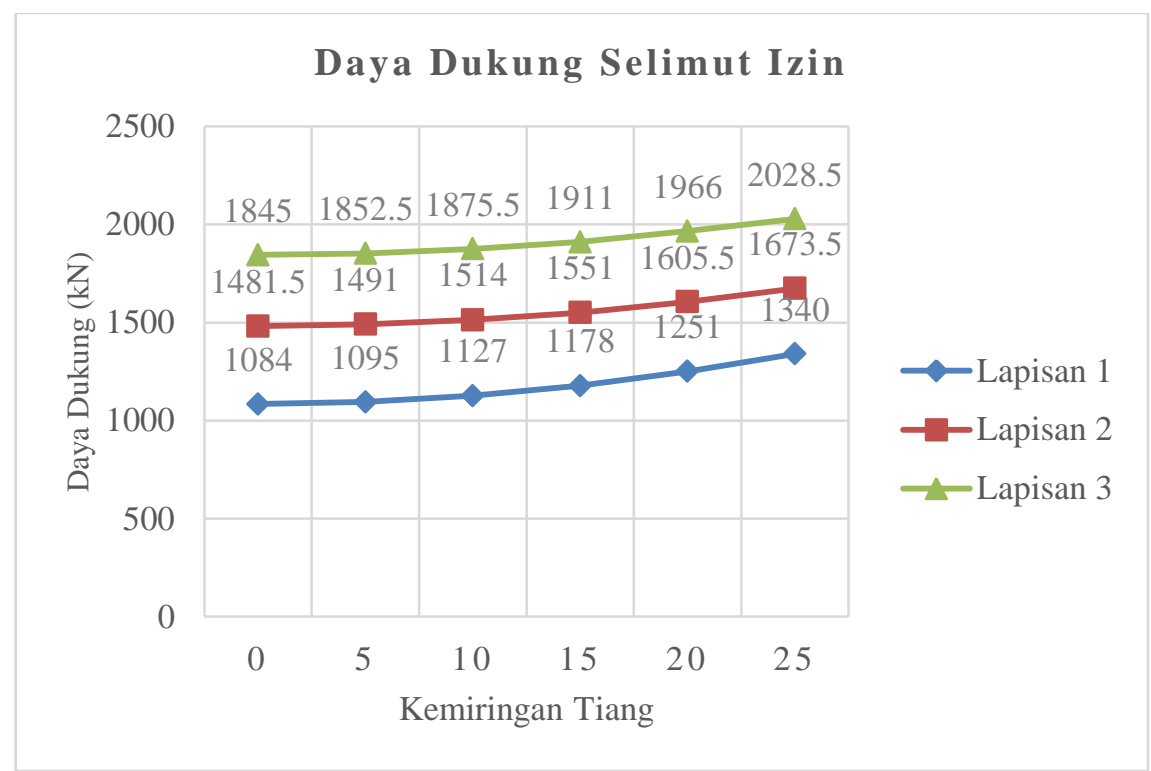

Gambar 5. Perubahan Daya Dukung Selimut Izin

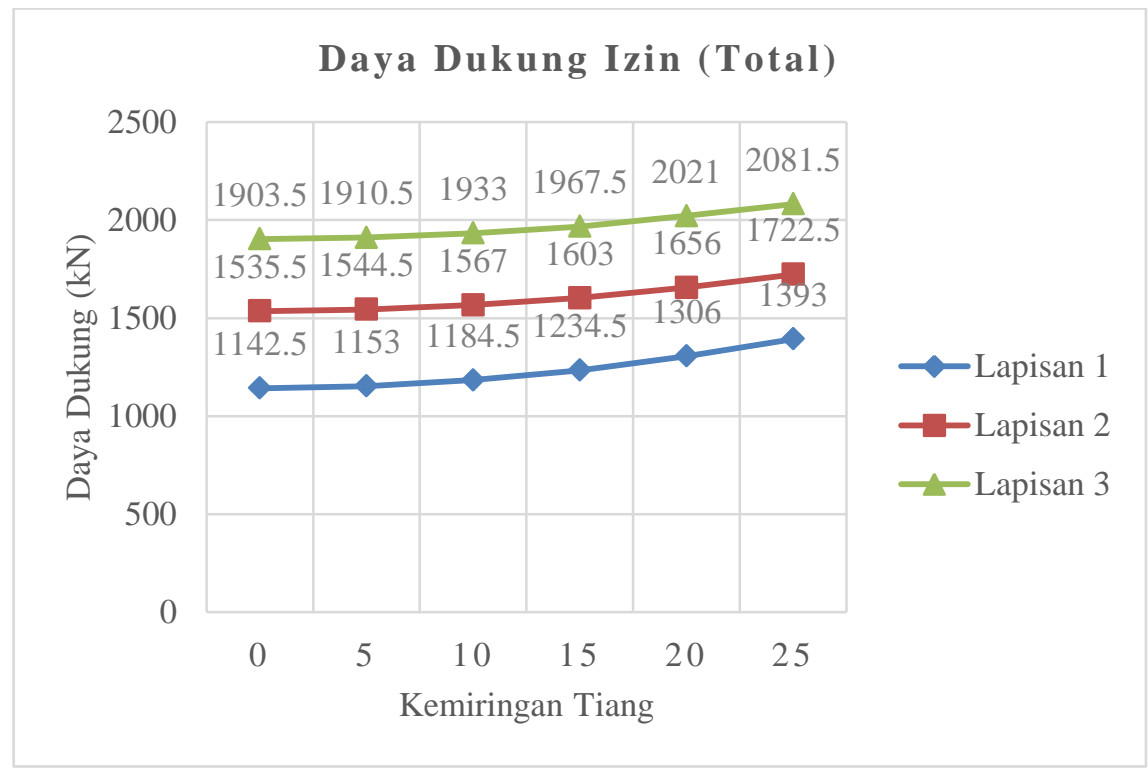

Gambar 6. Perubahan Daya Dukung Izin (Total) 


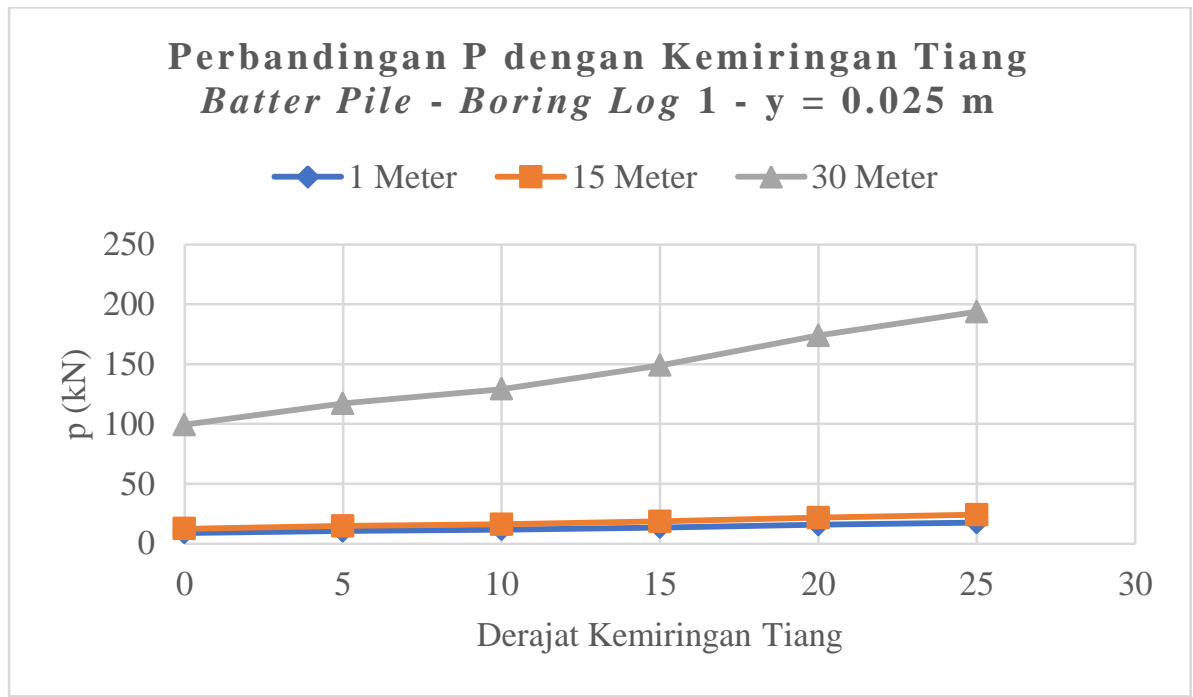

Gambar 7. Perbandingan P dengan Kemiringan Tiang - Boring $\log 1$

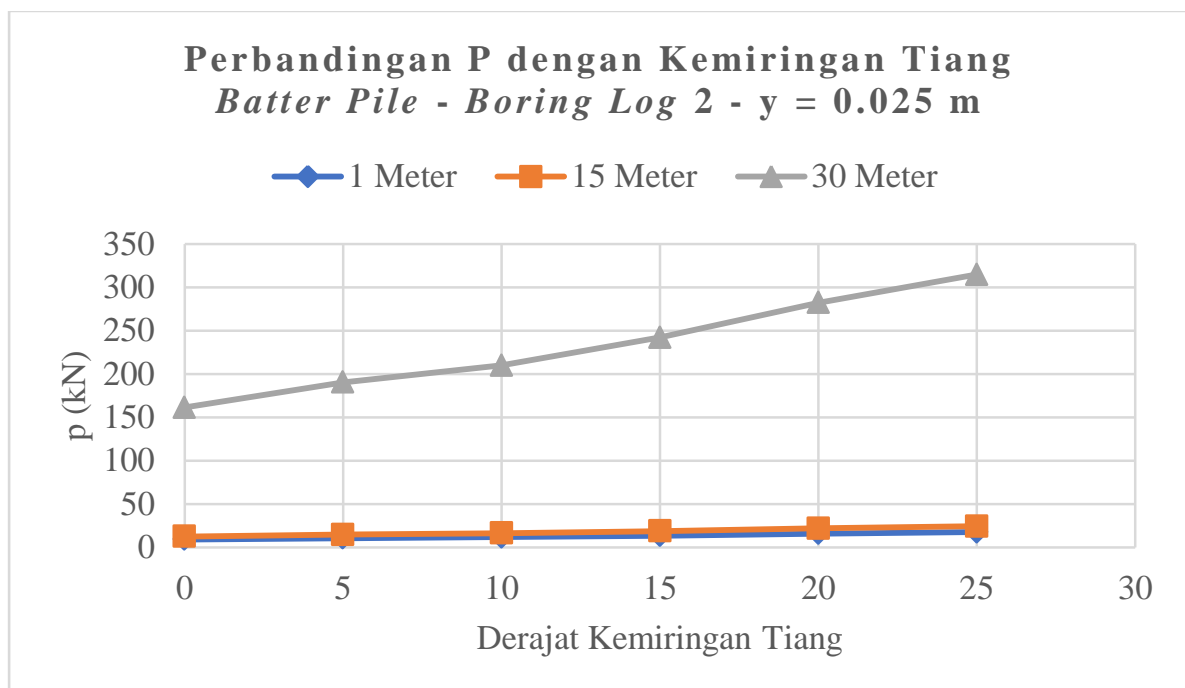

Gambar 8. Perbandingan P dengan Kemiringan Tiang - Boring log 2

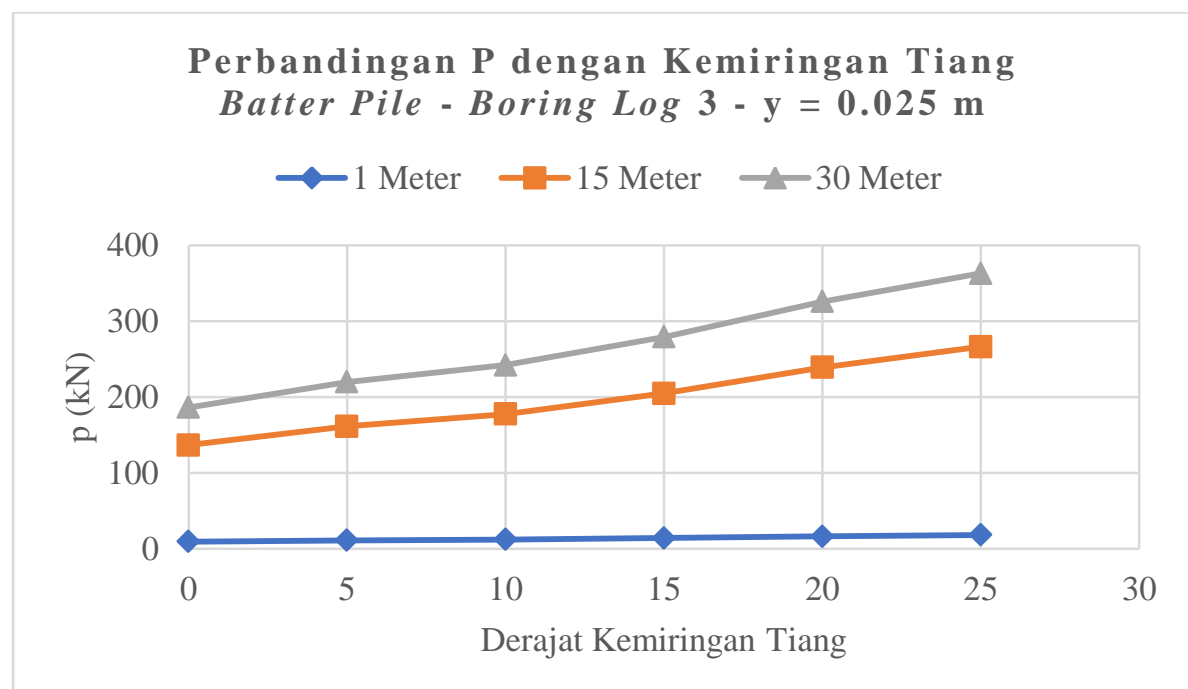

Gambar 9. Perbandingan P dengan Kemiringan Tiang - Boring log 3 


\section{KESIMPULAN}

\section{Kesimpulan}

Berdasarkan analisis yang telah dilakukan, dapat ditarik beberapa kesimpulan;

1. Seperti dapat diamati pada Gambar 4, daya dukung ujung tiang (aksial) akan menurun berbanding terbalik dengan meningkatnya sudut kemiringan tiang. Penurunan daya dukung terbesar terjadi pada rentang kemiringan $+20^{\circ}$ hingga $+25^{\circ}$, dengan $36 \%$ dari total penurunan daya dukung terjadi pada rentang kemiringan tersebut.

2. Seperti dapat diamati pada Gambar 5, daya dukung selimut tiang (aksial) meningkat sejalan dengan meningkatnya sudut kemiringan tiang. Namun perlu dipertimbangkan peningkatan panjang tiang yang terjadi akibat dari kemiringan tiang.

3. Seperti dapat diamati pada Gambar 6, daya dukung izin total meningkat sejalan dengan meningkatnya sudut kemiringan tiang. Hal ini dikarenakan nilai daya dukung selimut tiang yang jauh melebihi nilai daya dukung ujung tiang, sehingga pengaruh kenaikan daya dukung selimut terhadap daya dukung izin total lebih besar dibanding pengaruh penurunan daya dukung ujung tiang.

4. Seperti dapat diamati pada Gambar 7-9, pada parameter y konstan di 0.025 meter, daya dukung lateral meningkat sejalan dengan kenaikan sudut kemiringan tiang. Peningkatan daya dukung terbesar terjadi pada rentang kemiringan $+15^{\circ}$ hingga $+20^{\circ}$, dengan $26 \%$ dari total peningkatan daya dukung terjadi pada rentang kemiringan tersebut.

\section{Saran}

Berdasarkan hasil penelitian dan kesimpulan yang telah dirumuskan, saran yang dapat diberikan antara lain;

1. Desain tiang batter pile sesuai digunakan untuk menahan beban lateral dengan peningkatan kemampuan daya dukung yang signifikan, peningkatan daya dukung terbesar terjadi pada rentang kemiringan $+10^{\circ}$ hingga $+15^{\circ}$.

2. Pada desain tiang end bearing pile, pengaruh penurunan daya dukung akibat kemiringan sudut tiang perlu diperhatikan. Pengaruh penurunan ini lebih minimal pada desain tiang friction pile. Rentang penurunan kritis terjadi pada kemiringan antara $+20^{\circ}$ hingga $+25^{\circ}$.

3. Penelitian lebih lanjut diperlukan untuk memahami pengaruh kemiringan sudut tiang terhadap bending moment yang bekerja pada tiang.

\section{DAFTAR PUSTAKA}

Awoshika, K., Reese, L. C., Analysis of Foundation with Widely Spaced Batter Piles, Texas: U. S. Department of Transportation Federal Highway Administration, 1971

Boeckmann, A. J., et. al., Effect of Coupling on A-Walls for Slope Stabilization, Washington D. C.: U.S. Department of Transportation Office of the Assistant Secretary for Research and Technology, 2018

C. Chattopadhyay, B \& J. Pise, P., Uplift Capacity of Piles in Sand, Journal of Geotechnical Engineering, 112: ASCE, 1986

Hannigan, Patrick J., et. al., Design and Construction of Driven Pile Foundations, Washington D. C.: National Highway Institute, 2016

Indonesia. BAPPENAS. Pengembangan Tol Laut Dalam RPJMN 2015-2019 dan Implementasi 2015, Jakarta: BAPPENAS, 2015

Kementrian Koordinator Bidang Kemaritiman Republik Indonesia, PBB Verifikasi 16.056 Nama Pulau Indonesia, 2018, tersedia di: https://maritim.go.id/pbb-verifikasi-16-056-nama-pulau-indonesia/ diakses 15 Januari 2019

Kubo, J., Experimental Study of the Behaviour of Laterally Loaded Piles, Proc. $6^{\text {th }}$ International Conference, Vol. 2.: SM and FE, 1965

Matlock, H., Correlation for Design of Laterally Loaded Piles in Soft Clay. doi:10.4043/1204-MS, Austin: Offshore Technology Conference, 1970

Murthy, V. N. S., Geotechnical Engineering: Principles and Practices of Soil Mechanics and Foundation Engineering, London: CRC Press, 2002

PT. Pelindo IV, Menteri BUMN Resmikan 16 Proyek Strategis Senilai Rp2,153 Triliun di Kawasan Timur Indonesia, 2018, tersedia di: https://inaport4.co.id/read/20171204/552/menteri-bumn-resmikan-16proyek-strategis-senilai-rp2153-triliun-di-kawasan-timur-indonesia diakses 15 Januari 2019

Reese, L. C., Van Impe, W., Single Pile and Pile Groups Under Lateral Loading $2^{\text {nd }}$ Edition, London: CRC Press, 2001 
